\title{
MIGRATED PHARYNGEAL FISH BONE CAUSING SPONDYLODISCITIS. CASE REPORT
}

\author{
ESPONDILODISCITE CAUSADA POR ESPINHA DE PEIXE MIGRADA PARA FARINGE. \\ RELATO DE CASO
}

\section{ESPONDILODISCITIS CAUSADA POR ESPINA DE PESCADO MIGRADA PARA LA FARINGE. RELATO DE CASO}

Aluizio Augusto Arantes Júnior ${ }^{1,2}$, Jose Augusto Malheiros ${ }^{1,2}$, Marco Tulio Domingos Silva e Reis ${ }^{1}$, Gustavo Meyer de Moraes ${ }^{3}$

\begin{abstract}
Ingestion of foreign bodies is a common problem seen at emergency rooms and frequently involves chicken and fish bones. There are few cases of migrated foreign bodies through the retropharynx causing infectious process in the area but no one, despite the proximity, causing spondylodiscitis. Perhaps such condition is attributed to the integrity of the longus colli fascia covering and protecting the cervical spine. We described the first case of spondylodiscitis due to a foreign body (saw-toothed fish bone) that penetrated the longus colli fascia and carved into vertebral body C3.
\end{abstract}

Keywords: Discitis; Foreign bodies; Foreign-body migration; Fascia.

\section{RESUMO}

A ingestão de corpos estranhos é problema comum nos pronto-socorros e geralmente ocorrem com ossos de aves e espinhas de peixes. Há alguns relatos de casos de migração de corpos estranhos para a retrofaringe, que causam processo infeccioso local, mas não há nenhum caso descrito de espondilodiscite (apesar da proximidade). Talvez a ausência de infecção na coluna vertebral decorra da integridade da fáscia do músculo longo do pescoço, que recobre e protege a coluna cervical. Descrevemos o primeiro caso de espondilodiscite em decorrência de migração de uma espinha serrilhada de peixe que penetrou profundamente na fáscia do músculo longo do pescoço e atingiu o corpo vertebral de C3.

Descritores: Discite; Corpos estranhos; Migração de corpo estranho; Fáscia.

\section{RESUMEN}

La ingestión de cuerpos extraños es un problema común en los puestos de primeros auxilios y, generalmente, ocurre con huesos de aves y espinas de pescados. Hay algunos relatos de casos de migraciones de cuerpos extraños para la retrofaringe, las cuales causan procesos infecciosos locales, pero no hay ningún caso descrito de espondilodiscitis (aun considerando la proximidad). Quizás la ausencia de infección en la columna vertebral resulte de la integridad de la fascia del músculo largo del cuello, que recubre y protege a la columna cervical. Describimos el primer caso de espondilodiscitis causado por la migración de una espina serrada de pescado, la cual penetró profundamente en la fascia del músculo largo del cuello y alcanzó al cuerpo vertebral de C3.

Descriptores: Discitis; Cuerpos extraños; Migración de cuerpo extraño; Fascia.

\section{INTRODUCTION}

Ingestion of foreign bodies is a common problem seen at emergency rooms and frequently involves chicken and fish bones., When the foreign bodies become impacted, an endoscopic or direct oral removal is usually possible. However, migration of the foreign body through the pharynx is a rare complication. There are few reports of the migration of foreign bodies into unusual locations and complications in the literature. (Table 1) In this paper, we will review the literature and we will describe the first case of a foreign body causing cervical spondylodiscitis.

\section{CASE REPORT}

A 57-year-old man looked for medical assistance after dinner, complaining of odynophagia. The first oral evaluation showed a retropharyngeal puncture injury without any signs of a foreign body (that was under beneath the mucosa). Plain radiographs of the neck showed a radio-opaque foreign body adjacent to the $\mathrm{C} 2-\mathrm{C} 3$ space. A computed tomography (CT) scan (Figure 1a-b) was then performed and showed a 3-cm pointed bone carved into the vertebral body of C3.

After a couple of days, a direct laryngoscopy was performed. It was possible to notice the injury in the retropharyngeal mucosa. The removal of the foreign body was made extending an incision through the mucosa puncture and exploring the wound. Two direct laryngoscopies were needed (10 days between both) for the removal of the saw-toothed fish bone (Figure 1c). The surgical procedure resulted in clinical improvements and resolution of the odynophagia. However, after 45 days, the patient presented with fever, severe cervical pain radiating to his upper limbs and a stiff neck. His laboratory evaluation showed a high erythrocyte sedimentation rate (ESR), high levels of C-reactive protein (CRP) and neutrophilic leukocytosis. Magnetic resonance imaging (MRI) of the neck showed enhanced paravertebral tissue, disc space C2-C3 and epidural abscess (Figure 1d).

A high cervical retropharyngeal approach was performed and it was noticed adherences in the soft tissues and a small amount of purulent material in paravertebral space in continuity with longus colli fascia and intervertebral space. Then, we performed a standard C2-C3 discectomy without bone grafting. A sample taken for bacterial culture was negative.

1. Division of Neurosurgery, Luxemburgo Hospital, Belo Horizonte, MG, Brazil.

2. Division of Neurosurgery, Federal University of Minas Gerais, Belo Horizonte, MG, Brazil.

3. Division of Head and Neck Surgery, Federal University of Minas Gerais, Belo Horizonte, MG, Brazil.

Study conducted in Luxemburgo Hospital, Belo Horizonte. MG. Brazil.

Correspondence: Rua dos Inconfidentes 320/801, Belo Horizonte. MG, Brazil, 30140-120. aluizio_arantes@uol.com.br 
Table 1. Uncommon foreign body migration after ingestion.

\begin{tabular}{|c|c|c|c|}
\hline Location & Type & Complication & Author \\
\hline Facial artery and submandibular gland & Globefish bone - straight shape & Facial artery injury and submandibular hematoma & Chung et al. ${ }^{2}(2008)$ \\
\hline Sternocleidomastoid muscle & Korean bullhead fish bone - saw-toothed shape & Neck abscess & Chung et al. ${ }^{2}(2008)$ \\
\hline Retropharyngeal space & Saw-toothed fish bone & Retropharyngeal abscess & Chung et $a .^{2}$ (2008) \\
\hline Cricopharynx & Chicken bone & Paraesophageal abscess, mediastinitis & Kamath et al. $^{5}(1998)$ \\
\hline Skin of the neck & Sharp fish bone & Subcutaneous abscess & Chen et al..$^{1}(2009)$ \\
\hline Retropharyngeal space & Metallic wire & Retropharyngeal edema & Murthy et al. ${ }^{11}$ (1995) \\
\hline Skin of the neck & Fish bone & Subcutaneous abscess & Maseda et al. ${ }^{8}(2006)$ \\
\hline Thyroid gland & Fish bone & Thyroid abscess & Lu et al. ${ }^{7}(2000)$ \\
\hline
\end{tabular}

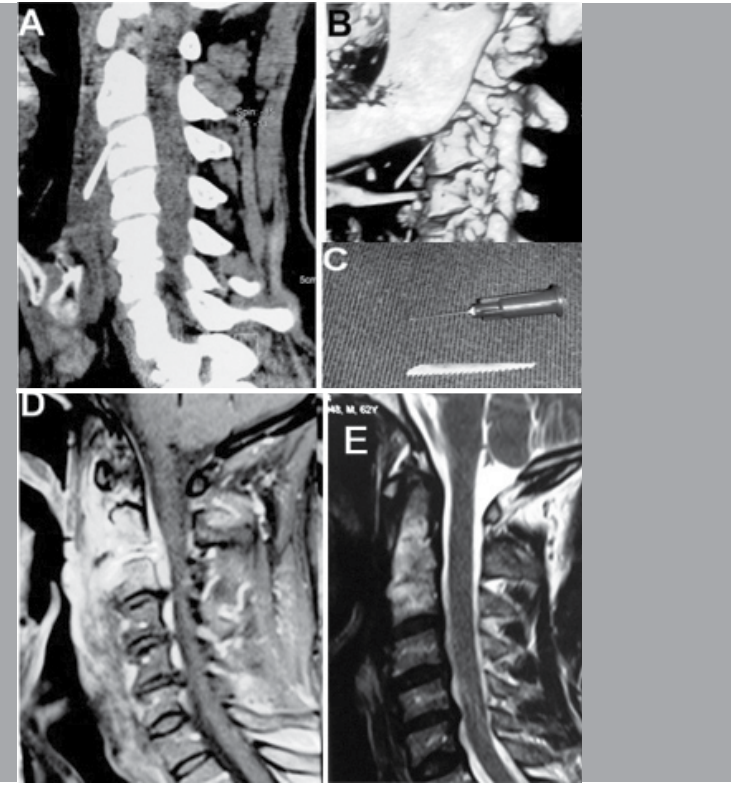

Figure 1. (A) The sagittal CT scan shows a linear radio-opaque foreign body carved into the C3 vertebral body. (B) Tridimensional CT scan reconstruction of the spine and the fish bone. (C) The saw-toothed fish bone that was removed and an insulin needle as a reference. (D) Sagittal T1-weighted MRI showing gadolinium enhancement of paravertebral and epidural space as well as the disc space $\mathrm{C} 2-\mathrm{C} 3$, indicating a diagnosis of spondylodiscitis.

An antibiotics course of ciprofloxacin and clindamicin was prescribed for 28 days. After three month of follow-up, the patient is asymptomatic, showed remarkable improvement according to both clinical and laboratory tests and the x-ray obtained showed C2-C3 fusion.

\section{DISCUSSION}

The shape of the foreign body is the most important factor in the pathology of migration. ${ }^{1,8}$ The literature describes saw-toothed fish bo- nes as being capable of penetrating deeper into the retropharyngeal space. The saw-toothed shape allows easy penetration but difficult backward removal, causing more injury to the mucosa. In our case, removal was only possible after the second oral surgical procedure.

The most common complication with foreign body migration is abscess of soft tissues. ${ }^{1,2,5,8,12}$ In this case, approximately 45 days after the fish bone was removed, the patient began to exhibit signs and symptoms of cervical spondylodiscitis. Our patient exhibited the criteria for a diagnosis of spondylodiscitis ${ }^{9-13}$ based on combination of clinical (cervical pain and fever), laboratory (increased values of ESR and CRP and leukocytosis) and MRI findings (contrast enhancement of paravertebral soft tissues and disc space).

There have been a few reported cases of paravertebral and retropharyngeal abscess, 2,5,7,10,12 but spondylodiscitis has never been reported with proximity to this area. We propose that the longus colli fascia covering the cervical spine serves as an important barrier against infection in the adjacent area. In our particularly case, the foreign body was carved into the C3 vertebral body and perforated this fascia, allowing the infection to reach the disc space.

One important difference in the treatment of this patient was the selection of antibiotics. Based on the upper gastrointestinal flora, antibiotics for gram-negative and anaerobic gram-negative bacteria were selected instead of those for gram-positive bacteria, especially Staphylococcus species. ${ }^{9-13}$ The remarkably clinical and laboratory improvement allowed us to confirm the efficiency of the antibiotics.

The migration of ingested foreign bodies into the pharynx is rare and unpredictable. An imaging examination is mandatory when the physician is suspicious of foreign body migration. A CT examination is one of the most important tools in the first evaluation of these patients because the majority of migratory foreign bodies are radio-opaque. MRIs are important for follow-up evaluation and complications. When a foreign body becomes impacted in the cervical spine and perforates the longus colli fascia, it can cause spondylodiscitis.

All authors declare no potential conflict of interest concerning this article.

\section{REFERENCES}

1. Cheng YC, Lee WC, Kuo LC, Chen CW, Lin HL. Protrusion of a migrated fish bone in the neck. Am J Otolaryngol. 2009;30(3):203-5.

2. Chung SM, Kim HS, Park EH. Migrating pharyngeal foreign bodies: a series of four cases of saw-toothed fish bones. Eur Arch Otorhinolaryngol. 2008;265(9):1125-9.

3. Honda K, Tanaka S, Tamura Y, Asato R, Hirano S, Ito J. Vocal cord fixation caused by an impacted fish bone in hypopharynx: report of a rare case. Am J Otolaryngol. 2007;28(4):257-9.

4. Joshi $A A$, Bradoo RA. A foreign body in the pharynx migrating through the internal jugular vein. Am J Otolaryngol. 2003:24(2):89-91.

5. Kamath MP, Shanmugam, Shetty AB, Prasad KC. A rare complication of an impacted foreign body in the cricopharynx. Am J Otolaryngol. 1998;19(1):61-5

6. Lannigan FJ, Newbegin CJ, Terry RM. An unusual subcutaneous neck lump. J Laryngo Otol. 1988; 102(4):385-6.

7. Lu PK, Brett RH, Aw CY, Singh R. Migrating oesophageal foreign body-an unusual case.
Singapore Med J. 2000;41(2):77-9

8. Maseda E, Ablanedo A, Baldó C, Fernández MJ. Migration and extrusion from the upper digestive tract to the skin of the neck of a foreign body (fish bone). Acta Otorrinolaringol Esp. 2006;57(10):474-6

9. Sreetharan SS, Prepageran N, Singh S. Migratory foreign body in the neck. Asian J Surg. 2005;28(2):136-8

10. Mastronardi L, Rychlicki F, Tatta C, Morabito L, Agrillo U, Ducati A. Spondylodiscitis after lumbar microdiscectomy: effectiveness of two protocols of intraoperative antibiotic prophylaxis in 1167 cases. Neurosurg Rev. 2005;28(4):303-7.

11. Murthy PS, Bipin TV, Ranjit R, Murty KD, George V, Mathew KJ. Extraluminal migration of swallowed foreign body into the neck. Am J Otolaryngol. 1995;16(3):213-5.

12. Osinubi $\mathrm{OA}$, Osiname $\mathrm{Al}, \mathrm{Pal} \mathrm{A}$, Lonsdale RJ, Butcher C. Foreign body in the throat migrating through the common carotid artery. J Laryngol Otol. 1996;110(8):793-5.

13. Titlic M, Josipovic-Jelic Z. Spondylodiscitis. Bratisl Lek Listy. 2008;109(8):345-7. 